Chapman University

Chapman University Digital Commons

Art Faculty Articles and Research

Art

1994

\title{
Design Education and the Quest for National Identity in Late Imperial Russia: The Case of the Stroganov School
}

Wendy Salmond

ChapmanUniversity, salmond@chapman.edu

Follow this and additional works at: http://digitalcommons.chapman.edu/art_articles

Part of the Art and Design Commons, and the Slavic Languages and Societies Commons

\section{Recommended Citation}

Salmond, Wendy. "Design Education and the Quest for National Identity in Late Imperial Russia: The Case of the Stroganov School," Studies in the Decorative Arts, 1.2 (1994): pp. 2-24.

This Article is brought to you for free and open access by the Art at Chapman University Digital Commons. It has been accepted for inclusion in Art Faculty Articles and Research by an authorized administrator of Chapman University Digital Commons. For more information, please contact laughtin@chapman.edu. 


\section{Design Education and the Quest for National Identity in Late Imperial Russia: The Case of the Stroganov School}

\section{Comments}

This article was originally published in Studies in the Decorative Arts, volume 1, issue 2, in 1994.

\section{Copyright}

University of Chicago Press 
WENDY R. SALMOND

\section{Design Education and the Quest for National Identity in Late Imperial Russia: The Case of the Stroganov School}

Of the three major industrial art schools operating in Russia on the eve of the 1917 Revolution, the Imperial Central Stroganov School of Technical Design in Moscow was the oldest, the most innovative, and the most controversial. ${ }^{1}$ The Stroganov School was the first art institution in Russia to confront the daunting problems of molding consumer taste and of improving manufactured goods aesthetically by providing the Empire's factories, workshops, and schools with well-trained industrial artists. For over half a century, it blazed a trail for other industrial art schools to follow, as its museum facilities, curriculum, publications, exhibitions, workshops, and factory internships all demonstrated a thoughtful and imaginative adaptation of modern Western ideas to local conditions. Above all, the Stroganov was known for championing a distinctively Russian style in manufactured objects, its mission being to wean Russian consumers from what was considered their inordinate love of foreign products while at the same time opening up new markets for Russian goods abroad.

None of these goals was at all unique to Russia, of course. That the national economy of any industrializing nation could benefit from the injection of aesthetics and the marks of national distinctiveness into various manufacturing sectors was an accepted fact by the mid-nineteenth century, and the proliferation of industrial art schools throughout Europe, England, and America acknowledged the role that art education was believed capable of playing in economic life. What made the Stroganov School's mission so unusual, and so problematic, was the matrix of social, cultural, and economic factors in which it operated. Allocated a central part in the creation of a new Russian producer and consumer, the Stroganov came face to face with long-standing issues of Russian identity that it was powerless to resolve. In its efforts to forge a stylistic compromise between Russian and European culture (the so-called Stroganov style was essentially a Russian variant of Art Nouveau), the school involuntarily exacerbated the tensions that arose when a traditional agrarian culture confronted the demands of modern industrial society.

Wendy R. Salmond is Assistant Professor of Art History at Chapman University, Orange, California. 


\section{The Pre-History of the School (1825-1859)}

Although it was not until 1860 that the Stroganov School was officially established, historians of the school have thought it important to begin their narrative in $1825 .^{2}$ In that year Count Sergei Stroganov, a prominent figure in Moscow artistic, literary, and archaeological circles, founded a "Drawing School Related to the Arts and Crafts" in Moscow. ${ }^{3}$ On a visit to Paris in 1822 the count had been "astonished by the perfection that the Parisian workers bring to all the goods produced in their workshops," and he attributed it to "the large number of educational institutions that serve all levels of society." ${ }^{4} \mathrm{He}$ particularly noted the emphasis placed on drawing. "Only with its aid," he wrote, "will [the worker] be able to attain that purity of form and confident execution without which the arts and crafts are now nothing." 5 Returning home, he received permission from Czar Alexander I to found a drawing school that would "teach elementary rules of practical Geometry, Architecture, and various kinds of drawing related to the Mechanical arts to artisans, apprentices, boys, and children of poor parents (both freemen and serfs), thereby providing them with the means to ply their principal trades with greater convenience and skill, and without resorting to outside help."6

An important practical motive for the count's generosity was his desire to counteract the strong preference that Russian consumers showed for foreign products, and their disdain for anything home-grown. "We decorate our rooms with French goods, and all the mechanical goods we use are English," he pointed out. "Luxury makes us a slave to the French, and a whimsical passion for improvements subjugates us to the English." Though his school might be obliged at first to borrow "models of refined taste and correctness" from more civilized nations, he cautiously hoped that Russia might in time develop those national qualities that made the products of France and England so admirable.

Before that could happen, however, the wretched status of the industrial and applied arts in Russia had first to be addressed. A systematic demotion of the industrial arts had begun earlier in the century when the Academy of Fine Arts dropped the teaching of crafts (masterstva) from its curriculum, thereby establishing the hegemony of the "free arts" of painting and sculpture (introduced from abroad by Peter the Great in the early 1700s) over traditional Russian crafts such as enamel, filigree, goldand silverwork, and wood carving. ${ }^{8}$ The lowly status thus conferred on a career in the useful arts was further compounded by the primitive state of Russian manufacturing and the undiscriminating tastes of the Russian public. On graduating from the count's school, many pupils gladly chose a poorly paid but socially respectable position as a drawing teacher in a 
remote provincial town, rather than take up the life of a factory draftsman, which was lucrative but viewed as uncouth and demeaning:

A manufacturer whose main purpose is to satisfy the tastes of the public has very specific demands in mind as regards patterns, and a young man who has graduated from a specialized educational institution must put aside those creative aspirations that his teachers inspired in him... The specialized artist is set to work copying ready-made designs adapted to public taste, and only after going through this training and adjusting to new conditions can he rely on a more or less stable income. Moreover, his personal aspirations and individual gifts are not free to develop and with every year become increasingly stifled. The artist disappears, leaving only the practical draftsman who not only fails to shape the tastes of the public, but actually spoils the little that society has gained from art. ${ }^{9}$

The Russian factory in the pre-Reform era was no place for those with artistic aspirations, and the complete lack of practical training received in the count's school virtually guaranteed that factory artists would fail in their lofty goals. When the school was transferred to the Ministry of Finance's jurisdiction in 1843, the curriculum was weighted still further toward training drawing and calligraphy teachers for the Empire's growing education system. It is not surprising, therefore, that the count's institution did more to define the massive problems facing industrial art education in Russia than to solve them.

\section{The Directorship of Victor Butovsky (1860-1881)}

The first of several metamorphoses in the history of the Stroganov School took place in 1859, when the Ministry of Finance merged it with a drawing school founded in 1836 by the Moscow Court Architectural Institute. The following year Victor Butovsky was appointed as the new school's director. A career bureaucrat in the Department of Trade and Industry, Butovsky had no formal training in the arts, but he did possess a keen appreciation of the measures needed to jolt Russian manufacturing out of its humiliating rut. After England's successes at the international exhibitions of the previous decade, no European nation could ignore the benefits of a state-sponsored industrial art education, and Russia's reputation for slavishly imitating the goods of other countries was now recognized as a significant deterrent to industrial growth. Butovsky's solution was to promote industrial art education as "one of the best means of ensuring the prosperity of the country, as well as strengthening national ideas." Under his direction, the Stroganov School was to lead a national campaign to give Russian manufacturing "that distinctive character in 
conjunction with artistry, the lack of which was one of the principal reasons for [Russian] industry's negligible significance in the eyes of Europe."10

By 1870 Butovsky had pushed through two astonishingly ambitious projects to promote the school as first and foremost a bastion of national ideas. Taking the South Kensington Museum and the museums of Lyons and Berlin as models, in 1863 he began to drum up support from Moscow manufacturers for a museum of industrial art. On the premise that Russian manufacturing should draw for inspiration on national ornamental traditions, he instituted a comprehensive plan for collecting in facsimile form (plaster casts and drawings) selected ornamental details from the major examples of pre-Petrine Russian architecture, applied art, and manuscripts. Together with genuine artifacts (enamels, niello, jewelry, plate, weapons, harness, fabrics, furniture, and liturgical objects), these facsimiles formed the basis of the Stroganov Museum's Russian section when it finally opened in 1868 (Fig. 1).

Encouraged by the response that a selection of the facsimile ornaments elicited at exhibitions in Moscow, Vienna, and Paris, Butovsky next undertook the monumental task of publishing one hundred manuscript illuminations, a volume he titled Histoire de l'ornement russe du Xe au XVIe siècle d'après les manuscrits (Fig. 2). In his foreword to this deluxe publication of 1870-1873, he defined its practical benefits as follows:

\footnotetext{
It attempts to show Russian artists and artisans the sources and types for a true national style.... It is a collection of materials and ideas for use in all areas of ornamentation: designs for fabric weaving and printing, decorations for furniture and furnishings, for works in gold and for jewelry, chasing and repoussé, ceramics, engraving, painting on glass and crystal, and bookbinding. ${ }^{11}$
}

To demonstrate that his claim could be realized, Butovsky set up several workshops attached to the museum on Miasnitskaia Street, and free access was given to anyone wanting practical experience in weaving, fabric printing, modeling, chromolithography, and painting on pottery, faïence, and porcelain. A variety of prototypes for the application of bona fide Russian ornament to functional objects were produced here, and these goods were exhibited and sold in the 1870s with considerable success. However, it was often artisans who actually produced these examples of an "Old Russian style," the Stroganov students themselves being involved in copying and compiling designs from the extensive resources now available to them, an activity that was evidently considered more suited to their creative aspirations. 
FIGURE 1

The Russian section of the Museum of Industrial Art attached to the Stroganov School, Moscow. From Iskusstvo $i$

khudozhestvennaia promyshlennost 3 (1898).
In all of these endeavors, Butovsky's attention seemed focused exclusively on changing the external perception of the Stroganov School as the necessary prerequisite to reforming it from within. This would explain his deferential attitude to French opinion, which at first glance sits rather oddly with his nationalist intentions. As his primary mentor, he chose not a noted Russian scholar, like Fedor Buslaev or Vladimir Stasov, but the French authority on industrial art, Natalis Rondot, whose three-part plan of 1858 for the Lyons Industrial Art Museum was adopted in full for Moscow. ${ }^{12}$ It was also at Rondot's prompting that Butovsky chose to have his Histoire de l'ornement russe published in Paris in 1870. Fully alive to the dangers of "design espionage" among the English, he appeared oblivious to any ulterior motives on Rondot's part. Thus, when Henry Cole and Owen Jones offered to buy some of his ornamental drawings at the 1867 Paris Exposition, Butovsky "was afraid of giving England our national designs and declined, demanding a far higher price." 13 But it took a cynical French observer, Alfred Darcel, to point out the value that a grammar of Russian ornament might have for French textile manufacturers: "If the Lyons silk makers are to continue to find an.

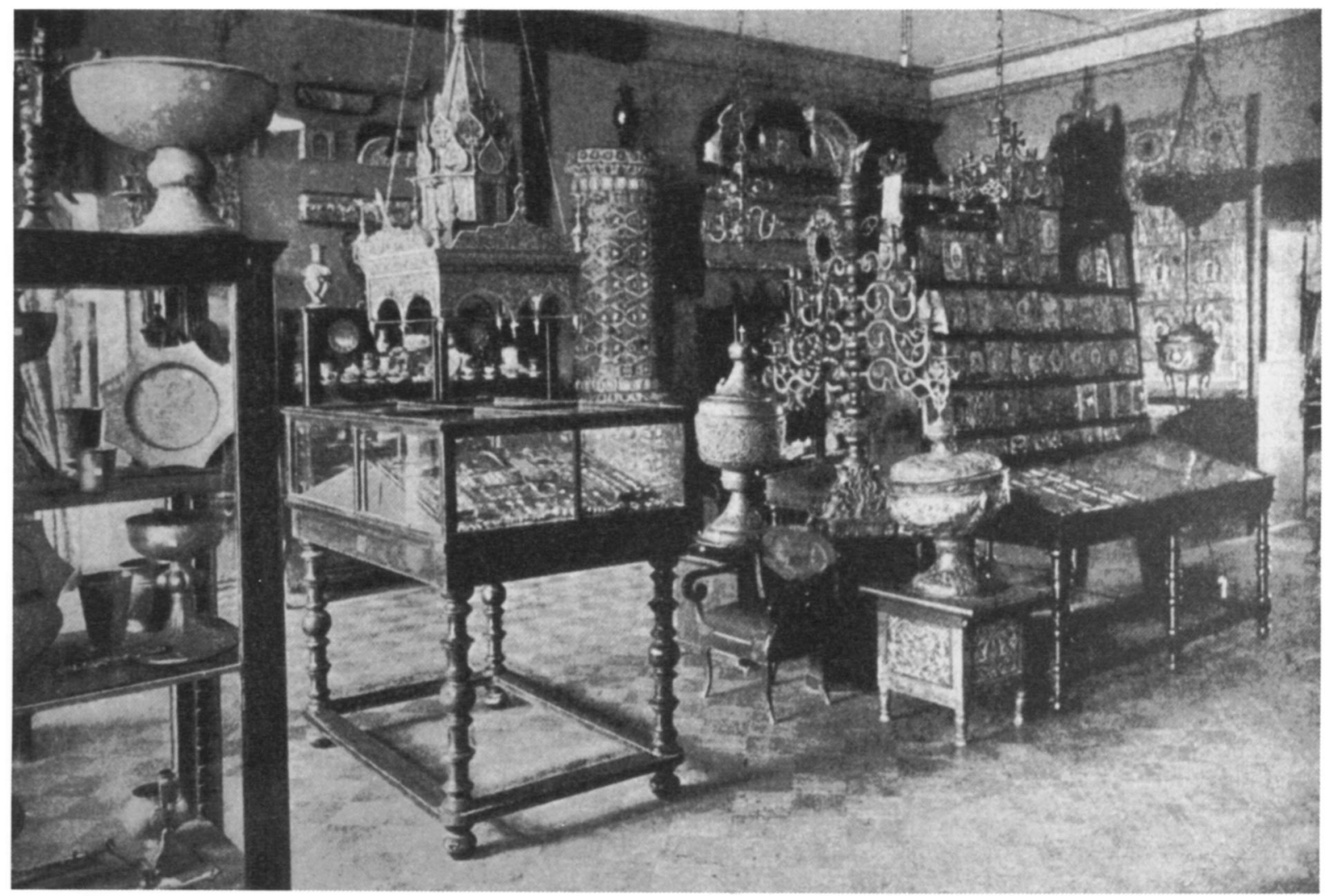




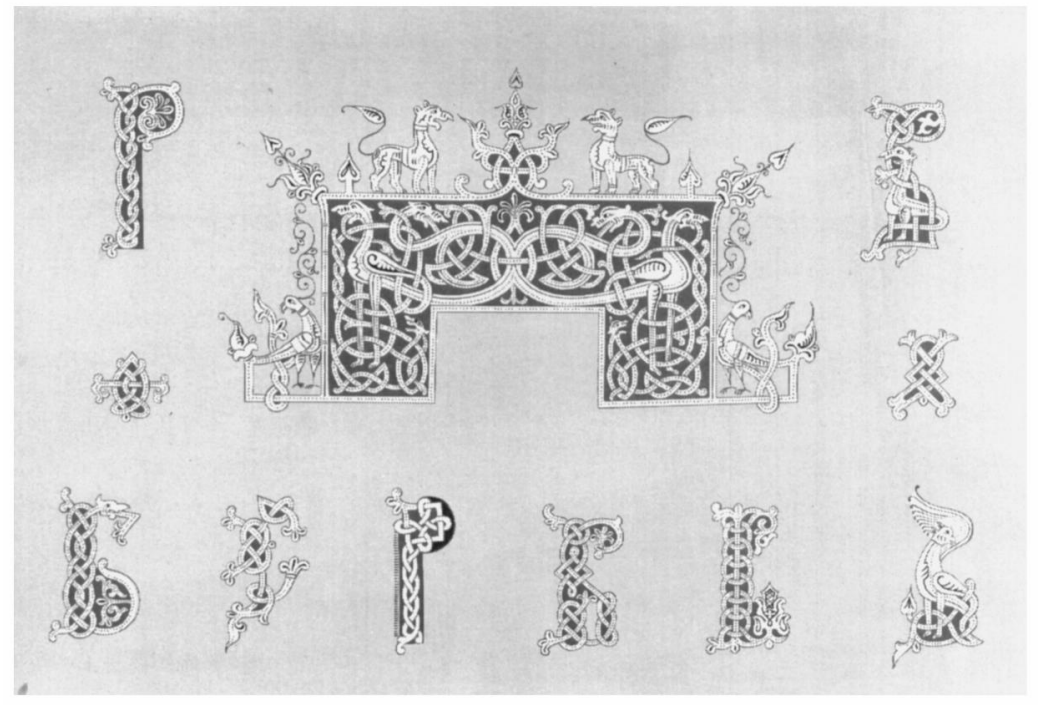

outlet in Russia," Darcel wrote, "they need to transform themselves in line with this revival of taste [for Russian popular art]."14 It seems probable that Butovsky deliberately chose to ally himself and his school with France, Europe's acknowledged capital of good taste. If Natalis Rondot praised the direction that the school had taken, what philistine Russian would dare to contradict him?

Butovsky's more scholarly compatriots were both impressed and irritated by the spectacle of Russia taken under the wing of France. True, he had succeeded in attracting foreign attention to his school and to traditional Russian culture, but why choose a French publisher over a Russian? Why was a grammar of Russian ornament, purportedly intended for humble Russian artisans, so prohibitively expensive (a hundred rubles for the complete set)? And why were Russia's Byzantine origins, with their unfortunate taint of cultural assimilation from without, privileged over all other sources of an ornamental renaissance, most notably those derived from peasant culture? According to his foremost critic, Vladimir Stasov, Butovsky was "full of patriotism, but full of ignorance too" in his attempts to revive an Old Russian style for the industrial arts based exclusively on the aristocratic habits of a Byzantine-dominated Russian court. "It is now clear to many people that there is no special honor for Russians in any sort of Byzantinism," Stasov wrote. "Does anyone now, except for Mr. Butovsky and his associates, have any desire merely to pass on stale foreign news?"15

Whatever its flaws, the Histoire d'ornement russe brought the Stroganov School, and Russian industrial art, to national and international prominence. It incited a healthy rivalry with the School of the Society for
FIGURE 2

Plate from Histoire de l'ornement russe du Xe au XVIe siècle d'après les manuscrits (Paris, 1870-1873). Photo: Getty Center for the History of Art and the Humanities, Santa Monica, California. 
the Encouragement of the Arts in St. Petersburg, which one year later published its own, very different version of a grammar of Russian ornament, Stasov's Russian Folk Omament. But perhaps most important for Butovsky's promotional purposes, his book earned the approval of visitors from abroad, such as the English critic A. Beavington Atkinson, who reported in 1872 that "l'École Stroganoff" might indeed be able to "supply those aesthetic wants which are never more keenly felt than at the turning point when a nation is passing out of barbarism into nascent civilization."16

\section{The Reforms of Nikolai Globa (1896-1917)}

Between 1881, the year of Butovsky's death, and 1896, the Stroganov School suffered a temporary setback. The workshops were closed down, funding was tight, and because of the lack of practical training most graduates took teaching positions in the provinces, much as they had in Count Stroganov's day. Meanwhile, Moscow was fast becoming the hub of a nation-wide railway network and the center of a rapidly growing textile industry. The Moscow industrial region's need for trained design personnel was urgent, and Butovsky's achievements had scarcely affected the realities of industrial production, as the following description of cut-andpaste design practices in a textile factory demonstrates:

Let's say a new pattern for a calico, batiste, upholstery cretonne, or velveteen is asked for. The factory has an artist for this purpose, but very rarely is this "artist" really one. In most cases he's a peasant from Kholui, Mstera, or Palekh, villages in Vladimir province employed exclusively in icon painting. The poor chap, having been raised on images with ascetic faces and figures, and straight drapery folds, turns up at the factory as a "draftsman," and instead of St. Basil or St. Nicholas he has to design "a nice jolly little pattern." ... He sits and sweats over his pattern making, using as models calico patterns that are already out of fashion. From one he takes a sprig, from another a leaf, a flower from a third, and voilà! a colorful monstrosity. ${ }^{17}$

The aesthetic shortcomings of Russian manufacturing were not lost on Count Sergei Witte, minister of finance from 1892 to 1903 and a strong supporter of both art education and industrial expansion. In 1896 Witte appointed his protégé, Nikolai Globa, to the post of Stroganov director. Globa was already well acquainted with the dismal state of industrial art education in Russia. A graduate of the Academy of Arts, he had taught for several years in the Women's Drawing Class at the Society for the Encouragement of the Arts in St. Petersburg, before being appointed 
inspector of industrial art education by Witte in 1895. In this capacity he helped to form the Society for the Propagation of Industrial Art Education in Moscow, with a membership including some of the city's leading textile magnates and manufacturers. ${ }^{18} \mathrm{He}$ also devised a plan for setting up specialized design schools throughout the Empire, but soon found the lack of trained instructors a serious obstacle. ${ }^{19}$

As the new director, Globa immediately undertook a set of sweeping reforms designed to transform the Stroganov from a drawing school into a fully fledged industrial art institute, where practical training would take its proper place alongside theoretical knowledge. Old workshops were reactivated and new ones gradually added, with funds from both the Ministry of Finance and the manufacturing sector: donations from the Sapozhnikov, Morozov, Mikhailov, and Rybakov firms, for example, helped to equip the reopened weaving workshop with six new looms. In 1897 Globa involved the city's industrialists still more closely in the school's affairs by introducing a system of annual design competitions, with local firms offering prizes for original patterns that could be put into immediate production. It now became obligatory for students to spend their summer holidays as factory interns in their fields of specialization.

Along with these practical measures, the school's already strong association with a national style was strengthened in every possible way. If at the beginning of his tenure Globa's aims were of the vaguest kind-“"to use drawing to develop the students' ability to capture the idea of artistic form, their understanding of the laws of beauty and refinement, and the communication of their ideas in beautiful forms that would satisfy the demands of developed aesthetic taste"-by 1900 the school's most important goal was "to direct the students' artistic instinct toward seeking and developing a distinctive beauty in national Russian art." ${ }^{20}$ Beginning in 1899, excursions were organized to St. Petersburg, Iaroslavl, Vladimir, Rostov, and other historic cities, "to acquaint students with old Russian architecture, painting and applied art, and also with peasant handicrafts and factory production." 21 When local jewelry, ceramics, or textile firms offered prizes in the annual design competitions, they frequently specified a Russian or Byzantine style. In 1899, for example, the five prizes were described as follows:

I. Prize for a hanging bronze lamp in the Louis XV or XVI style, given by Grand Duchess Elizaveta Fedorovna.

II. Prize for a jute upholstery fabric in the Russian style, given by V. G. Sapozhnikov.

III. Prize for a tombstone in a Byzantine or Russian style, given by A. List. 
IV. Prize for a complete silver writing set for a man's desk in the Russian style, given by M. P. Ovchinnikov.

V. Prize for a tea set in the Russian style, given by M. S. Kuznetsov and Co. ${ }^{22}$

Over time, the revival of national traditions became an integral part of the basic curriculum, which was now divided into a five-year Lower School program and three years of composition classes in the Upper School. The first two "history of style" classes taught at the Stroganov were devoted exclusively to Russian styles,

in view of the acknowledged ability of children to assimilate things with comparative ease and to remember them for the rest of their lives. Naturally, in a Russian school the study of one's native history, and in art schools of one's native art antiquities, should take precedence over the study of the art history of other nations, and one must think that the forms of one's native art, stored away during the years of greatest receptivity and curiosity, will always remain an unshakable foundation upon which ever-newer forms dear to the spirit of Russian art will subsequently be developed. ${ }^{23}$

In 1908 the drawing courses were reorganized and expanded to encourage greater independence and imagination. A class in "creative drawing" was introduced to develop "the creative abilities with which Russian youth are especially endowed, but which are usually stifled from earliest childhood by that urge to imitate that is so widespread in Russian society." 24 Instead of "the dry pedantic tracing of dull models, pupils [were] taught to make both line and color drawings of objects familiar to them from their home environment, or shown them from the Museum collection." 25 Academic drawing from casts was deferred until the fourth year, by which time pupils would have acquired "a sufficient store of their own individual thoughts and observations." 26 And in the senior composition classes for students in their final three years, the first class was devoted exclusively to designing in a Russian style.

These adjustments to a system of art education imported from abroad seem rational and necessary steps to producing a new breed of Russian designer, one capable of independent thought and naturally predisposed toward primary aesthetic habits acquired in childhood-in short, to a native Russian style. This, after all, was the goal to which Count Stroganov had hoped his school might aspire. But it was also the direction in which Russia was being prodded by other nations, not merely out of self-interest (to protect their own markets), but also in response to the specter of an industrialized world in which all nations would be culturally homogeneous. As the nineteenth century drew to a close, backward 
countries like Russia were increasingly exhorted to protect their preindustrial culture before it disappeared. In the words of one English observer, "What was wanted [in Russia] was that the national art should be fostered, so that the world should not become more commonplace, as the result of commercial enterprise and travelling facilities." 27 Free trade was a danger threatening that "Russia would be speedily supplied with wares from other European markets, which would ultimately lead to the same results that had to be deplored in India, the decay of native art."28 These veiled prescriptions were not lost on the Stroganov School's administration. It is no accident that the launching of a distinctive Stroganov style occurred at the 1900 Paris Exposition, where Art Nouveau and the cultures of countries hitherto dismissed as primitive were celebrated in tandem.

\section{The Stroganov Style}

Butovsky had established a Russian style for the Stroganov School that was rooted in the relatively new science of archaeology, and that stressed fidelity to original sources. By contrast, Globa's reforms promoted the concept of stylization as a fundamental design principle. Although artifacts continued to serve as models, the creative process was no longer confined to selecting ornament for passive reproduction. Students were now encouraged to transform motifs and forms through the prism of their fin-de-siècle age and their own experience. It could certainly be argued that, by distorting, exaggerating, and simplifying both natural forms and the national cultural heritage, they were only responding to the world as their medieval ancestors had done, or as the Russian peasant still did. ${ }^{29}$ But most observers merely saw the insidious influence of "Vienna and Munich chic" at work, a tendency dismissed as "decadence."

This fundamentally xenophobic conclusion was not reached immediately. Initially it was observed that "the attempt of the new director to raise the level of our wretched so-called industrial 'art' deserves every attention." 30 When the Stroganov School scored an unexpected and unprecedented success at the 1900 Paris Exposition, with two Grands Prix and six gold and six silver medals awarded by an international jury, the winning entries were praised precisely because they were "not simple copies of familiar motifs from our antiquities but free compositions based on our ancient style. One senses in them the breath of the past and something new, something unique to themselves." ${ }^{11}$

By 1901, however, a reviewer of the annual Stroganov exhibition sounded a note of caution: "The Russian style predominates, although some works reflect an enthusiasm for fashionable tendencies.... In the 
FIGURE 3

Design for a fireplace, c. 1898. From Zapiski Moskouskogo Arkhitekturnogo Obshchestva. Ezhegodnik 1 (1909).

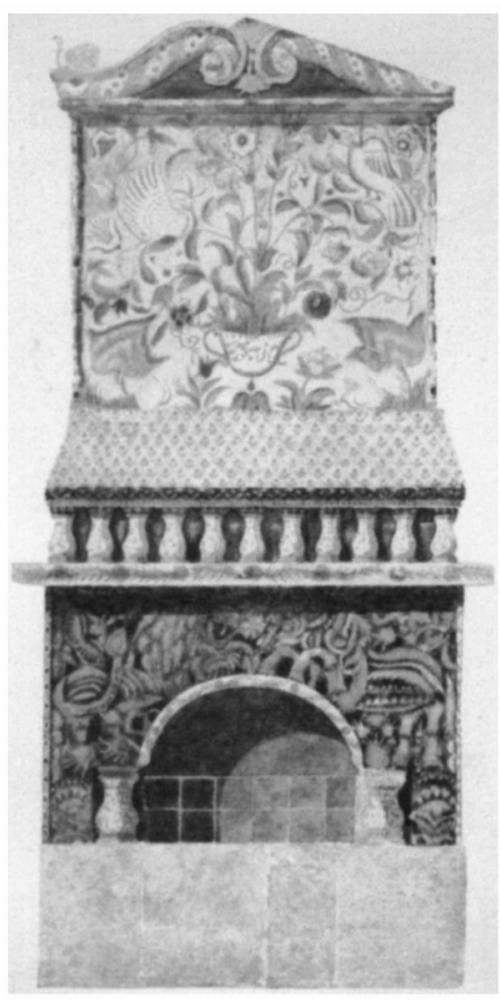

'Stylization of Flowers' class one senses a desire to 'go decadent.' "32 Two years later, it was observed in more pointed language that the school was "imbuing designs and finished objects with a life and nature that are foreign to our spirit, that are more like work from some German or new Zionist school.... Everything shown here reveals well-established principles of applied art borrowed from German style moderne publications. The workshops can go no further in this direction." 33

The immediate source of this problematic new style was not the availability of art journals such as Jugend, Pan, and Studio, as these reviews might suggest, but the Stroganov faculty itself, which from 1898 included the most progressive architects and artists then involved in articulating a new Russian style. To teach the senior composition classes, Globa invited the architects Fedor Shekhtel, Lev Brailovsky, Lev Kekushchev, Sergei Solovev, Konstantin Bykovsky, Ivan Zholtovsky, Sergei Vashkov, and Alexander Shchusev. Anatomy classes were taught by Sergei Goloushev, a medical doctor more famous for his art criticism, which appeared under the pseudonym Sergei Glagol. Konstantin Korovin, whose designs for the Russian pavilions at the 1900 Paris Exposition were widely seen as the first viable prototype for a neo-Russian style in architecture, was appointed head of the stage design program. And Mikhail Vrubel, then approaching the peak of his notoriety as a "decadent" painter, was invited to teach two new courses called "Plant Stylization" and "Exercises in Stylization."

During the 1890s, Vrubel had been the creative force behind the success of the Abramtsevo Ceramic Factory, a commercial enterprise funded by the railway magnate and art patron Savva Mamontov, where painters like Korovin, Valentin Serov, Vasily Polenov, and Vrubel experimented with art ceramics, majolica, and new glazes. Signs of the Abramtsevo influence can already be detected in a Stroganov student's design for a tiled fireplace (a favorite Vrubel project) from the late 1890s (Fig. 3). In itself a very "Russian" object, the fireplace combines two varieties of plant ornament (one traditional, one more fantastic) with the squat, bulbous columns that were an integral part of the Russian architectural vocabulary. Under the direction of the sculptor Nikolai Andreev, the Stroganov ceramics workshop acquired an international reputation for new forms, new ornamentation, and new high-fire glazes and metallic effects (Fig. 4). ${ }^{34}$

In the weaving and fabric printing workshops, the peculiar brand of neo-Russian ornament favored there was also indebted to the decorative experiments of artists from the Abramtsevo circle, above all to Elena Polenova, Alexander Golovin, and Natalia Iakovlevna Davydova. In the 1890s these artists had devised a new grammar of Russian ornament based 


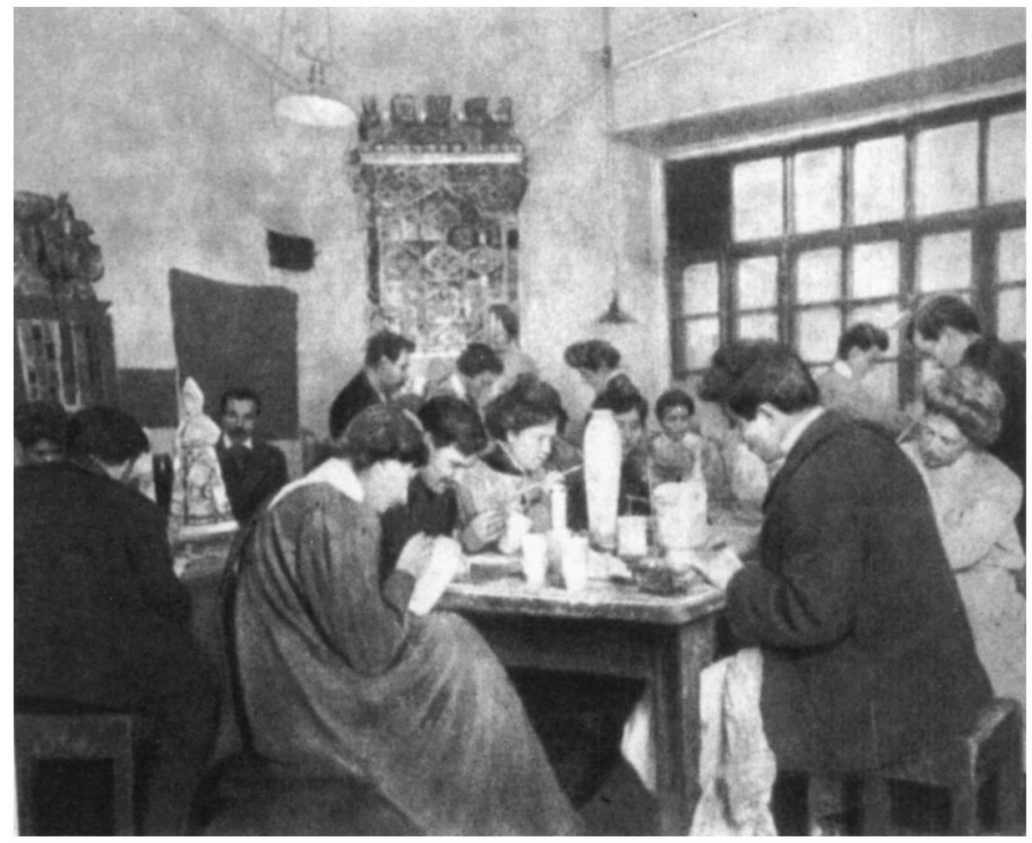

on stylized motifs from local flora and fauna, which was intended to breathe new life into Russia's declining kustar art industries-traditional peasant crafts such as embroidery, fabric printing, and wood carving. ${ }^{35}$ (Kustar was apparently a corruption of the German word Künstler, artist.) Their legacy is especially visible in two fabric designs that were published in a Moscow architectural journal in 1909. In one, a hen pecks at a sprawling bush with spatulate leaves that undulate upward to end in giant circular blooms (Fig. 5). The other, a repeat pattern of cloudberries and fantastic foliage on a dark ground (Fig. 6), recalls the splendid woven brocades for which Russia had long been famous, but more vividly it calls to mind the plant fantasies of Elena Polenova with their curiously grotesque hyperboles and expressionist stylizations. ${ }^{36}$

Stroganov pupils were also aware of activities at Talashkino, the Smolensk estate of Princess Maria Tenisheva, where a revival of peasant crafts was attempted in the early 1900s. Tenisheva's Moscow store The Source sold an array of one-of-a-kind decorative objects produced by peasant craftsmen using designs by prominent Moscow artists, and the princess was known to have selected two Stroganov graduates in 1903 to head her Talashkino workshops. ${ }^{37}$

Without access to the Stroganov's archives, any picture of the school's interaction with both the major centers of progressive design and the leading commercial firms remains frustratingly incomplete. ${ }^{38}$

It seems clear, however, that the school acted as the primary
FIGURE 4

The ceramic workshop of the Stroganov School, under the direction of Nikolai Andreev, early 1900s. From K. E. Pruslina, Russkaia keramika (Moscow, 1974). 
FIGURE 5

S. Markelov, design for the textile workshop at the Stroganov School. From Zapiski Moskovskogo Arkhitekturnogo Obshchestva. Ezhegodnik 1 (1909).

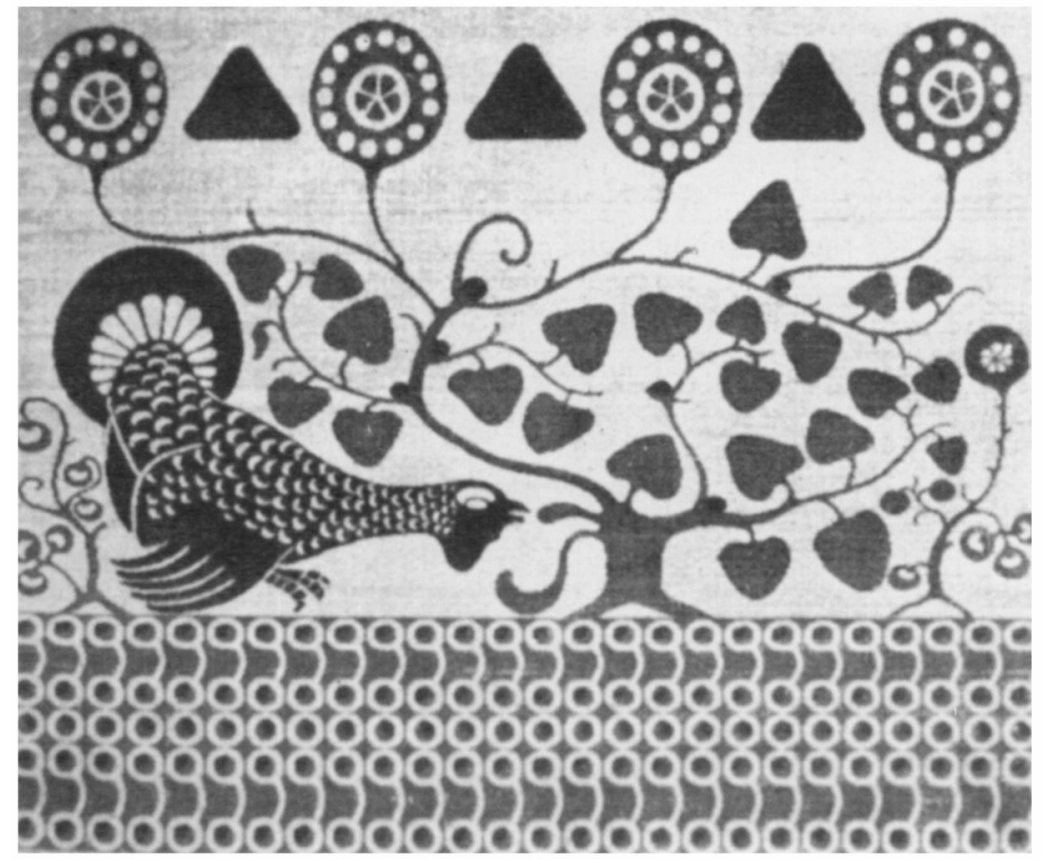

intermediary between the "avant-garde" Moscow art world and the middle-class consumer, disseminating its own form of Russian moderne through its store on Rozhdestvenka Street. Here the Moscow public could buy goods made in the school's seventeen workshops, including "ceramics, silver, bronze, copper work, enamels, furniture, icons, embroidery, textiles, glassware, work in leather and horn, bookbinding, chromolithography, etching, and other forms of printmaking." 39 Similarly, at the annual exhibitions of student work, the visitor could buy decorative objects of the kind featured in the poster advertising the 1913-1914 student exhibition: a metal cup with fernlike spirals for handles, a repoussé metal teapot, and a length of boldly printed naboika (block printed fabric) suitable for a portière (Fig. 7).

The decorative effect that could be achieved by combining the best efforts of all seventeen workshops was demonstrated in 1908, when the school exhibited several model interiors at the International Art and Construction Exhibition in St. Petersburg (Fig. 8). The walls of the cramped dining room were lined with cumbersome buffets, side tables, chairs, and a divan, hanging cupboards and shelves, decorative majolica, and wooden platters. On every surface, caskets and koushchi (both traditional Russian shapes in wood and metalwork) jostled Jugendstil clocks and vases. The dining table was set with every kind of decorative utensil, beneath the shadow of an impressive metal lampshade. The sheer 
clutter confirms the school's allegiance to the production of consumer goods rather than to the utopian aestheticization of everyday life.

\section{The Campaign for Graphic Literacy}

In 1902 the Stroganov's sphere of influence, previously confined to a fairly limited geographical area and a well-to-do social stratum, was dramatically expanded when the Ministry of Finance passed a Statute on Art Education. For the next decade the school became the nucleus of a nationwide campaign for "graphic literacy," training designers and teachers for all levels and branches of industrial production throughout

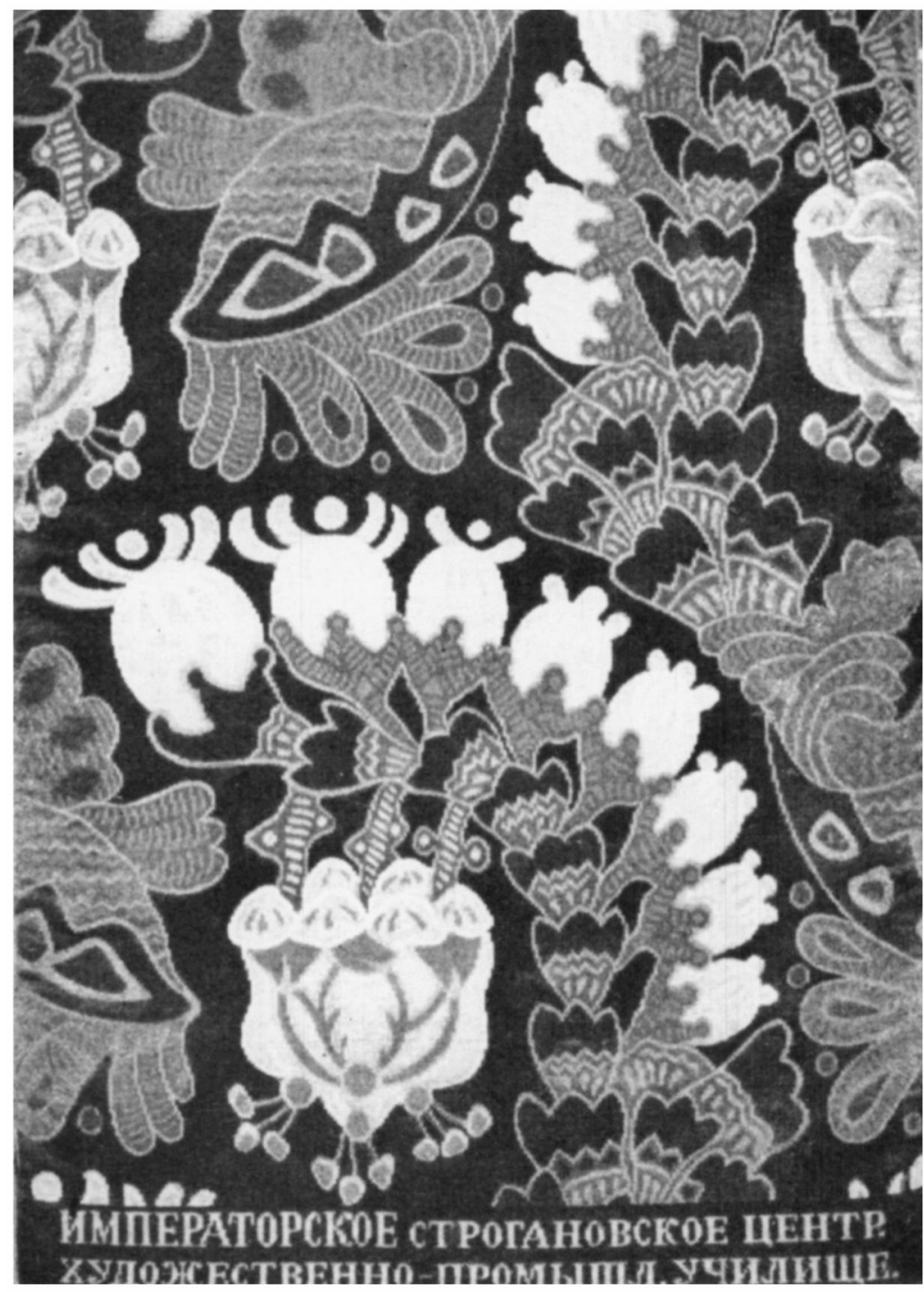

FIGURE 6

V. Akimov, design for the textile workshop at the Stroganov School. From Zapiski Moskouskogo Arkhitekturnogo Obshchestva. Ezhegodnik 1 (1909). 


\section{FIGURE 7}

Poster for the Exhibition of Student Work at the Stroganov School 1913-1914. From N. I. Baburina, Russkii plakat vtoroi poloviny XIX-nachala XX veka (Leningrad, 1988).

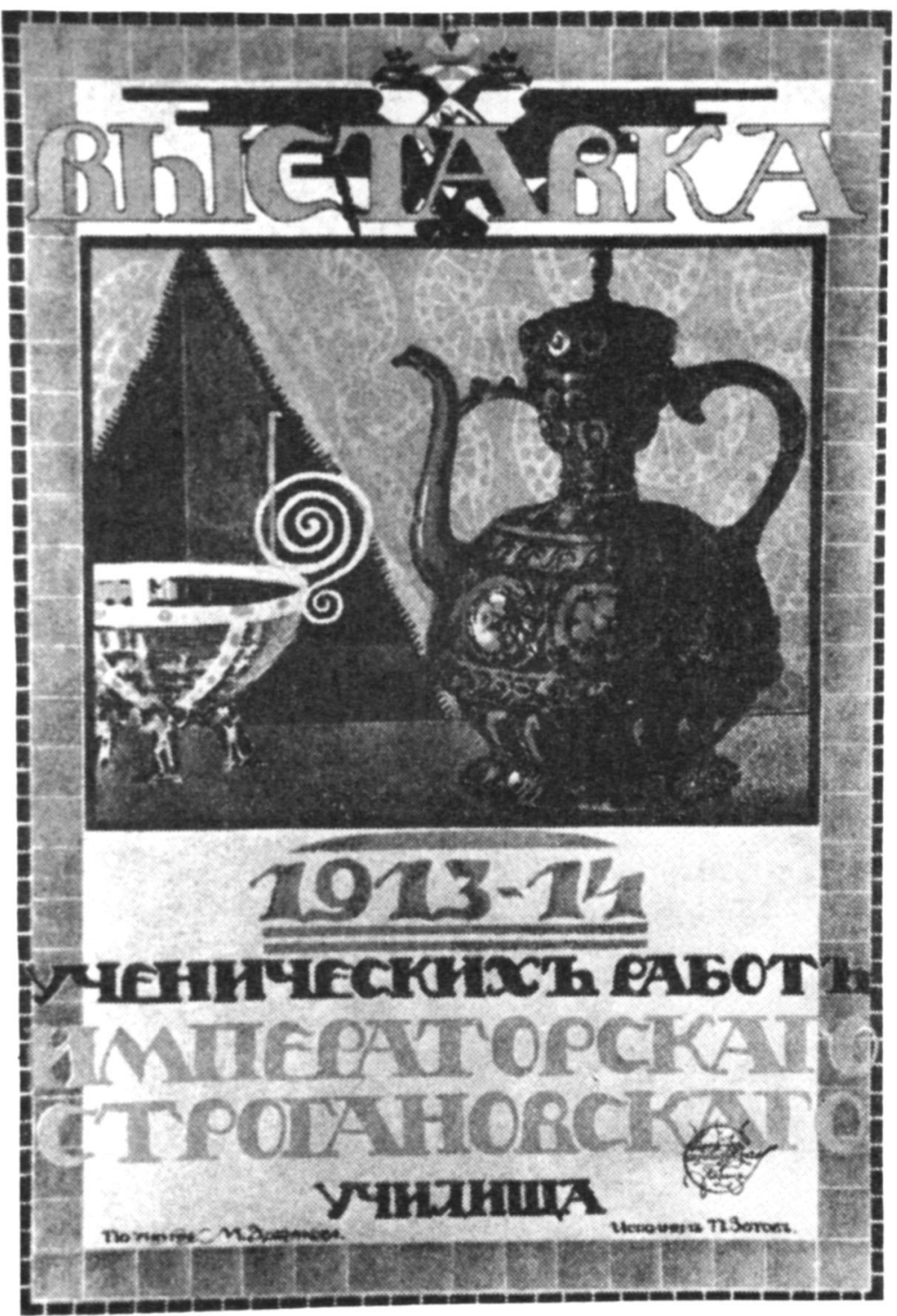

the Empire. ${ }^{40}$ Within its official purview now came all of those issues which the schools of fine art had traditionally ignored: "questions about the general aesthetic education of the people, about art in the life of the child at school, about the development of folk art through the kustar and the artisan, and the status and goals of our industrial art."41

Particular attention was given to the aesthetic education of Russia's kustar population, comprising some three million peasants who produced a range of consumer products under a cottage industry system. In the 1870 s the revival of certain kustar arts and crafts had been recognized as a 
potential source of revenue and a way of maintaining the social status quo in the countryside, while celebrating indigenous cultural traditions. Widely considered Russia's last direct link with those native arts which Western culture had supplanted in the eighteenth century, Russian kustar art was now perceived as an economic gold mine that with proper management could yield good returns.

The Stroganov's outreach effort began with the opening of branch schools in the villages of Ligachev, Rechitsa, Sergius Posad, and Ostrogozhsk, all important centers of kustar furniture, wood carving, and toy production. A network of schools and training workshops was subsequently established in key kustar districts like Kamenets-Podolsk in Poltava province, an area well known for its ceramics. A 1913 photograph of the Kamenets-Podolsk Arts and Crafts Training Workshop's production reflects the emphasis that the school's administration placed on all aspects of drawing (Fig. 9). Its director, Nikolai Root, ardently supported an art education system based on Western principles, claiming: "We have
FIGURE 8

The dining room exhibited by the Stroganov School at the International Art and Construction Exhibition in St. Petersburg, 1908. From Niva 32 (1908).

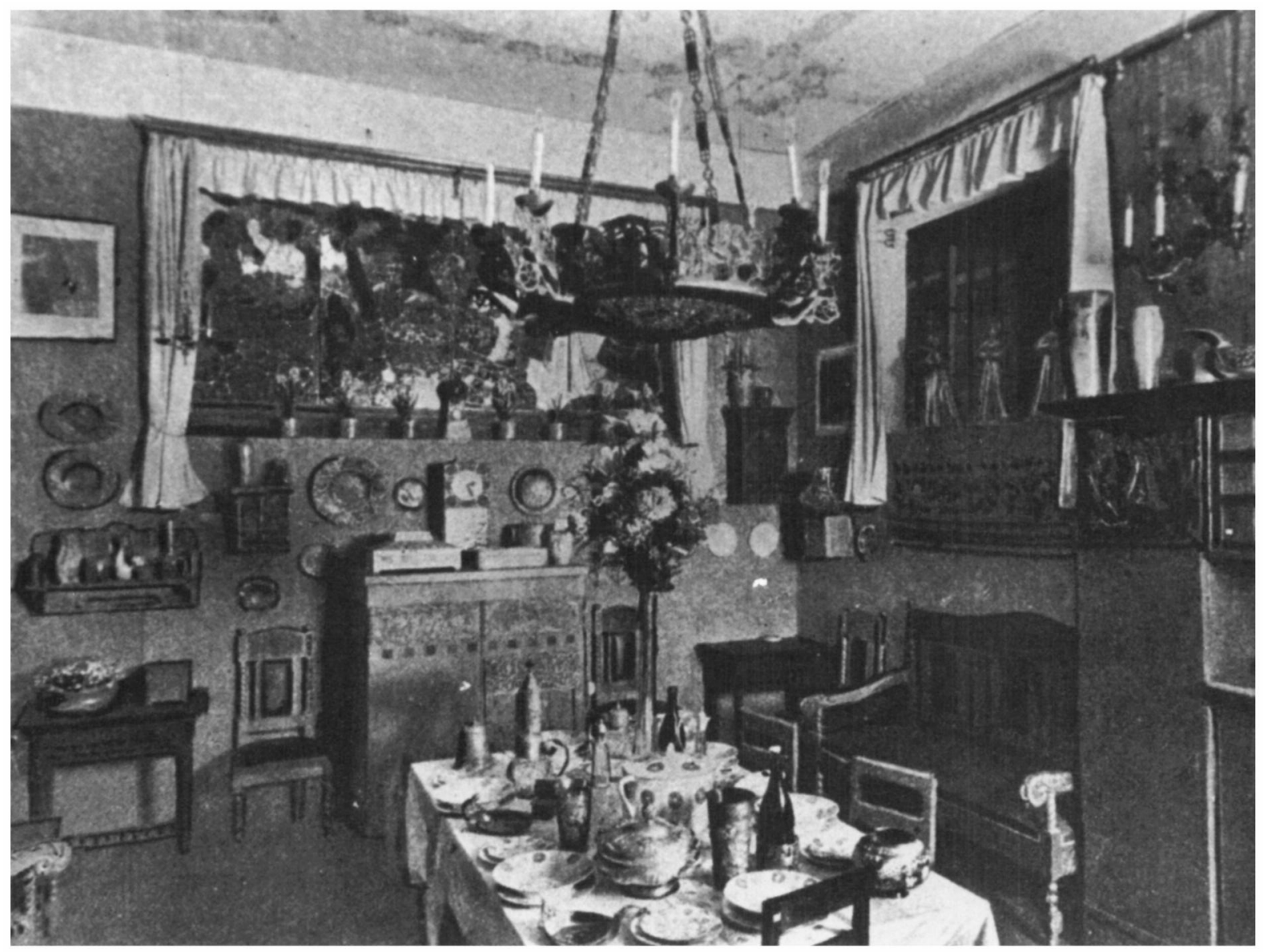




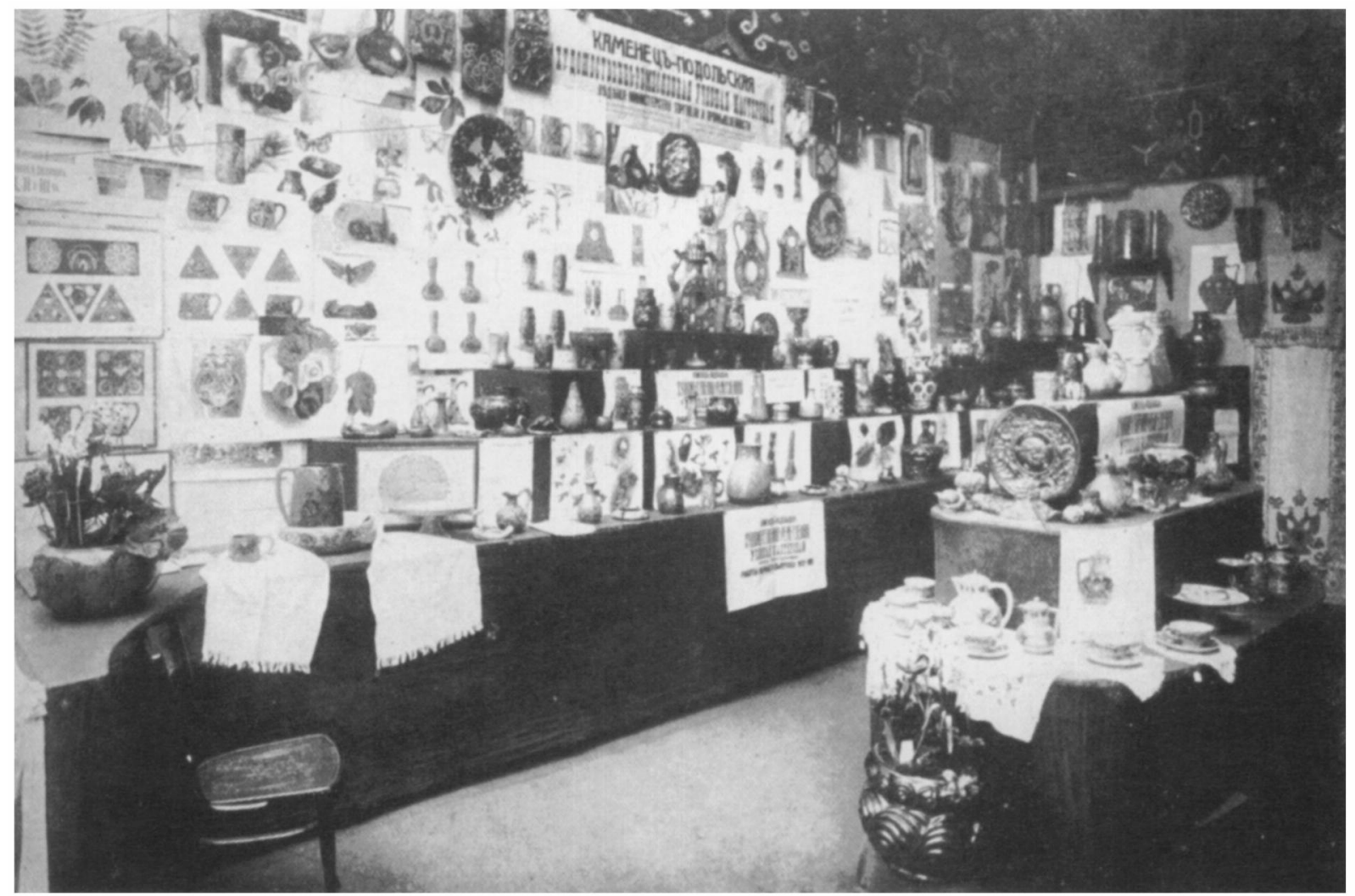

FIGURE 9

View of the Kamenets-Podolsk Arts and Crafts Training Workshop's section at the Second All-Russian Kustar Exhibition in Petrograd, 1914. From Solntse Rossii (1913). nothing to fear from the Europeanization of industrial art education. The Russian artist in the applied arts, having assimilated the achievement of Europe, as shown by the history of Russian art in all spheres, can create nothing that is not Russian and not national, if the basis for industrial art education is established on cultivated principles." 42 But as the campaign to educate the Russian kustar progressed, a major question arose. If peasant art were valued for its "naïveté, spontaneity, and colorful 'savagery,' "43_-for being "untutored"-would it be able to maintain those qualities in the face of an education system that valued correct drawing, technical precision, and refinement? Would the "real" Russian art practiced in countless peasant villages be able to hold its own against the reconstituted, updated style russe moderne officially espoused by the Stroganov School?

By 1913 several classes of "Stroganovtsy" trained under the Globa system had graduated and found positions either in factories and workshops, or as instructors and artistic directors in provincial schools. Some conscientiously practiced the nationalist principles that their alma mater had taught them. Ekaterina Vorobeva became director of the 
Mariinsky Lace School in St. Petersburg, a state-run school committed to the preservation of traditional women's handcrafts. During the 1910s and into the 1920s, a number of former students worked as staff artists for the important Moscow Kustar Museum in Leontievsky Lane, helping to design new products for a variety of kustar art centers. ${ }^{44}$ In the southern province of Poltava, V. I. Cherchenko developed a kind of "neoUkrainian" decorative style for the carpentry workshops run by the Poltava provincial zemstvo, or local government (Fig. 10).

There were also instances, however, where Stroganov-trained instructors were the source of extraordinary stylistic anomalies. Under the direction of four such instructors, students at the Bolshoe Krasnoe training workshop for gold- and silversmiths in Kostroma province were introduced to the Biedermeier revival then fashionable in the Russian capitals (Fig. 11). In similar fashion workers in the "Marble" Lapidary Training Workshop in the Urals town of Ekaterinburg produced frames, paperweights, and statuettes in a neo-Egyptian style, thanks to the initiative of the Stroganov-trained A. N. Shapochkin (Fig. 12).

Instances of this sort fueled a bitter debate over the wisdom of interference from government agencies such as the Stroganov School in
FIGURE 10

Carved sideboard made in the carpentry workshop of the Poltava provincial zemstvo, c. 1913. From Russkoe narodnoe iskusstvo na vtoroi vserossiiskoi kustarnoi vystavke v Petrograde v $1913 \mathrm{~g}$ (Petrograd, 1914).
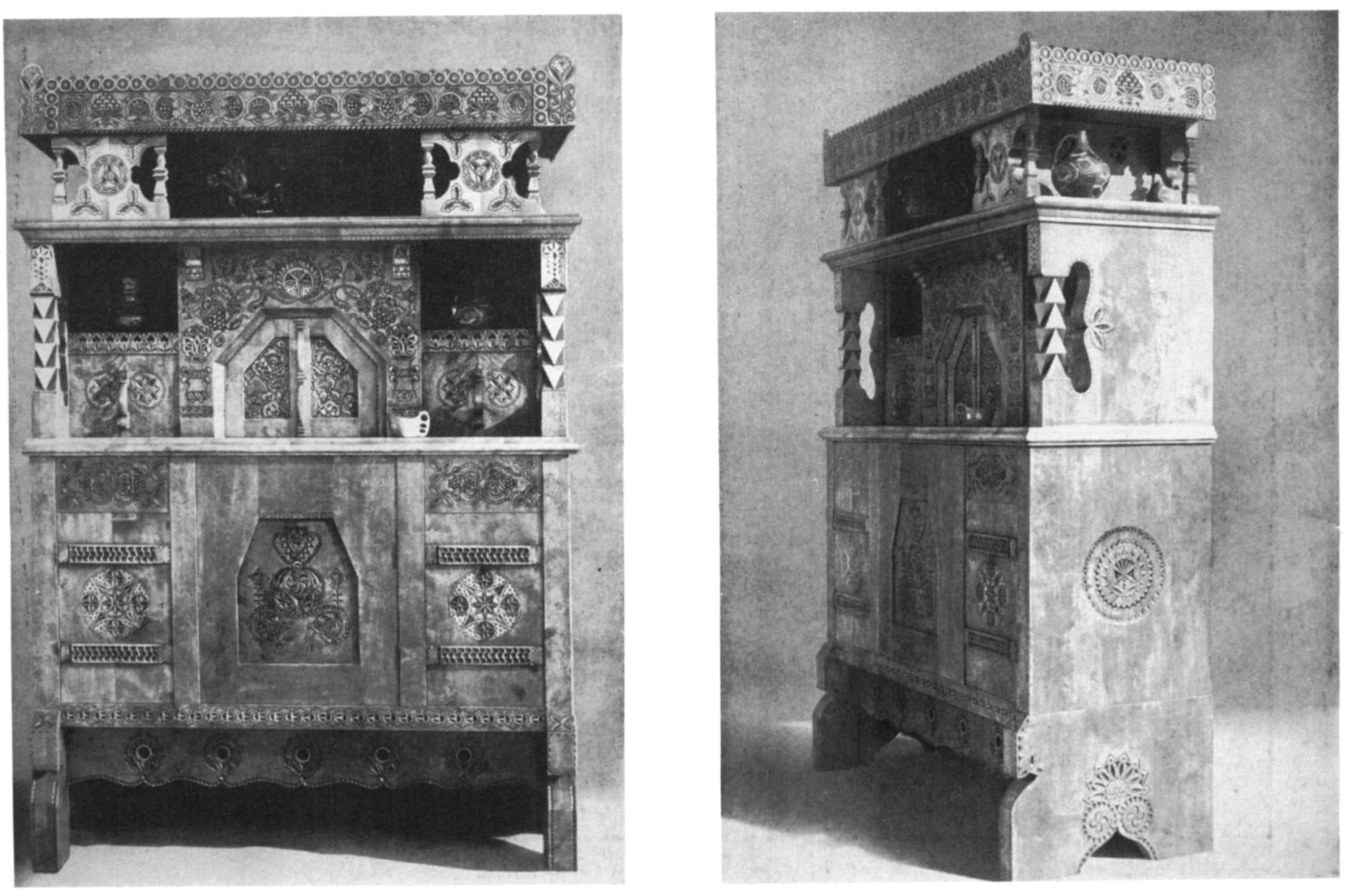


\section{FIGURE 11}

Silver, gilt, and enameled goods made by former students of the Bolshoe Krasnoe Arts and Crafts School, Kostroma province, c. 1913. From Russkoe narodnoe iskusstvo.

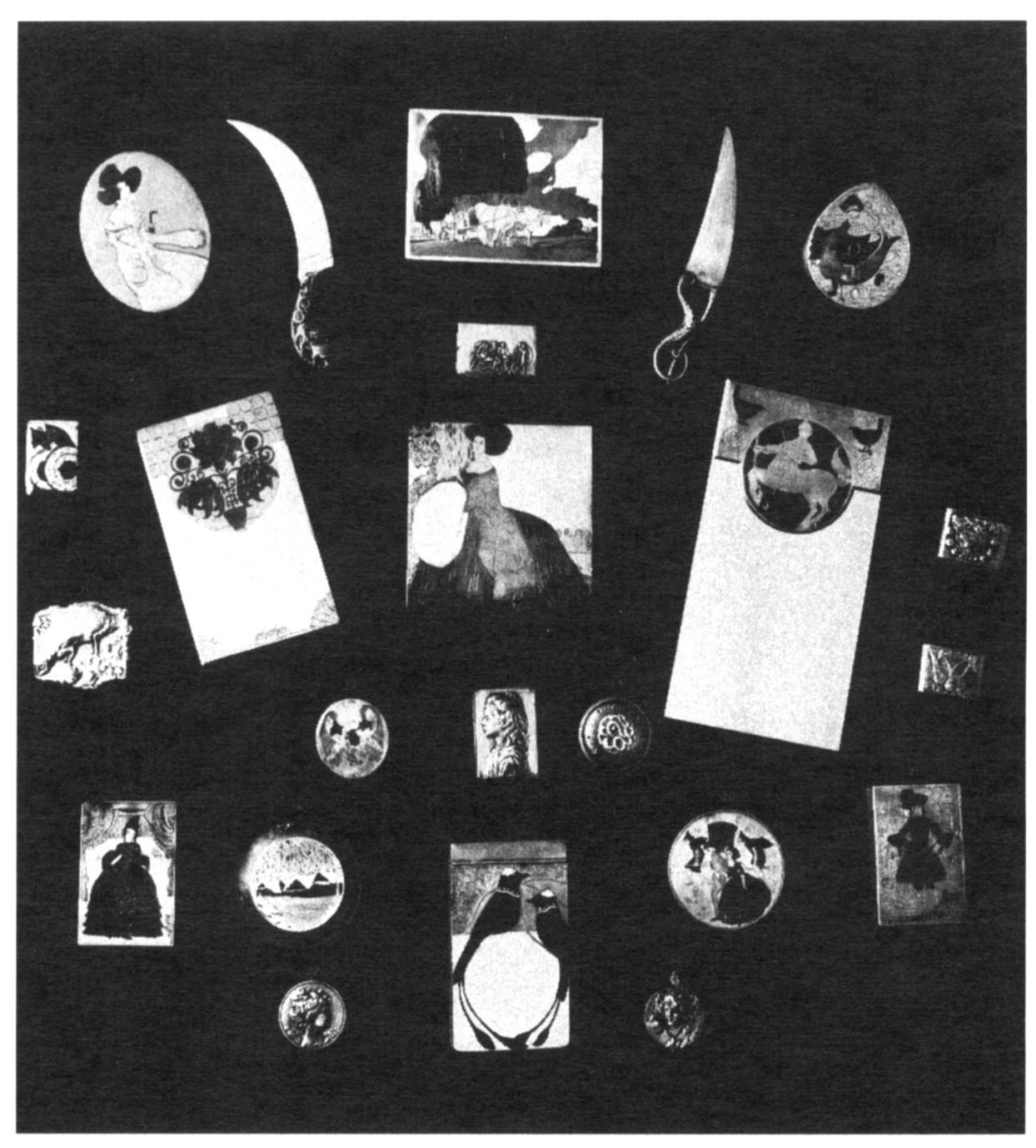

the natural evolution (or decline) of Russian peasant culture. Far from raising the wretched Russian kustar to a level of taste and culture on a par with that of Europe, the Stroganov seemed to conspire in eroding the last shreds of those qualities that constituted his absolute value and difference.

Such incidents also suggest that the "psychological training" in national values that the school tried to emphasize was both superficial and artificial. Few people, it seemed, really believed that the neo-Russian style, with its tendency toward theatrical excess and impracticality, was more than a clever marketing device best suited for international exhibitions and the export trade. Although the Stroganov School doggedly attempted "to instill in Russian society greater confidence in its own artistic powers and to have a broad moral and practical significance," 45 it ultimately proved powerless to withstand the tyranny of a consuming public that still looked to Europe to find out what it should buy. With the exception of religious art, where national style was always considered most appropriate, the demand for the neo-Russian style in everyday life lasted only as long as it was valued abroad. 


\section{The Stroganov School after 1917}

In theory, the history of the Imperial Central Stroganov School of Industrial Art ends in September 1918 when, by decree of the People's Commissariat of Enlightenment, it was amalgamated with the Moscow School of Painting, Sculpture, and Architecture to form the Free State Art Studios, or SVOMAS. Two years later the SVOMAS were reconstituted as the Higher State Art Studios, or VKhUTEMAS, and for several years the school was an arena for the experiments and debates of the Constructivist faction as represented by Alexander Rodchenko, Varvara Stepanova, and other young VKhUTEMAS faculty. ${ }^{46}$

Yet sweeping changes in name, structure, and personnel, designed to put as much distance as possible between the Soviet present and the discredited bourgeois past, could not wholly obliterate the very real continuity between VKhUTEMAS and the Stroganov School. For one thing, the VKhUTEMAS mission was virtually identical to that of its predecessor, dedicated to preparing "highly qualified master artists for industry as well as instructors and directors of professional and technical education," "developing and encouraging artistic activity among the
FIGURE 12

Carved marble and stonework made by pupils of the "Marble" Lapidary Training Workshop of the Ekaterinburg district zemstvo, Perm province, c. 1913. From Russkoe narodnoe iskusstvo.

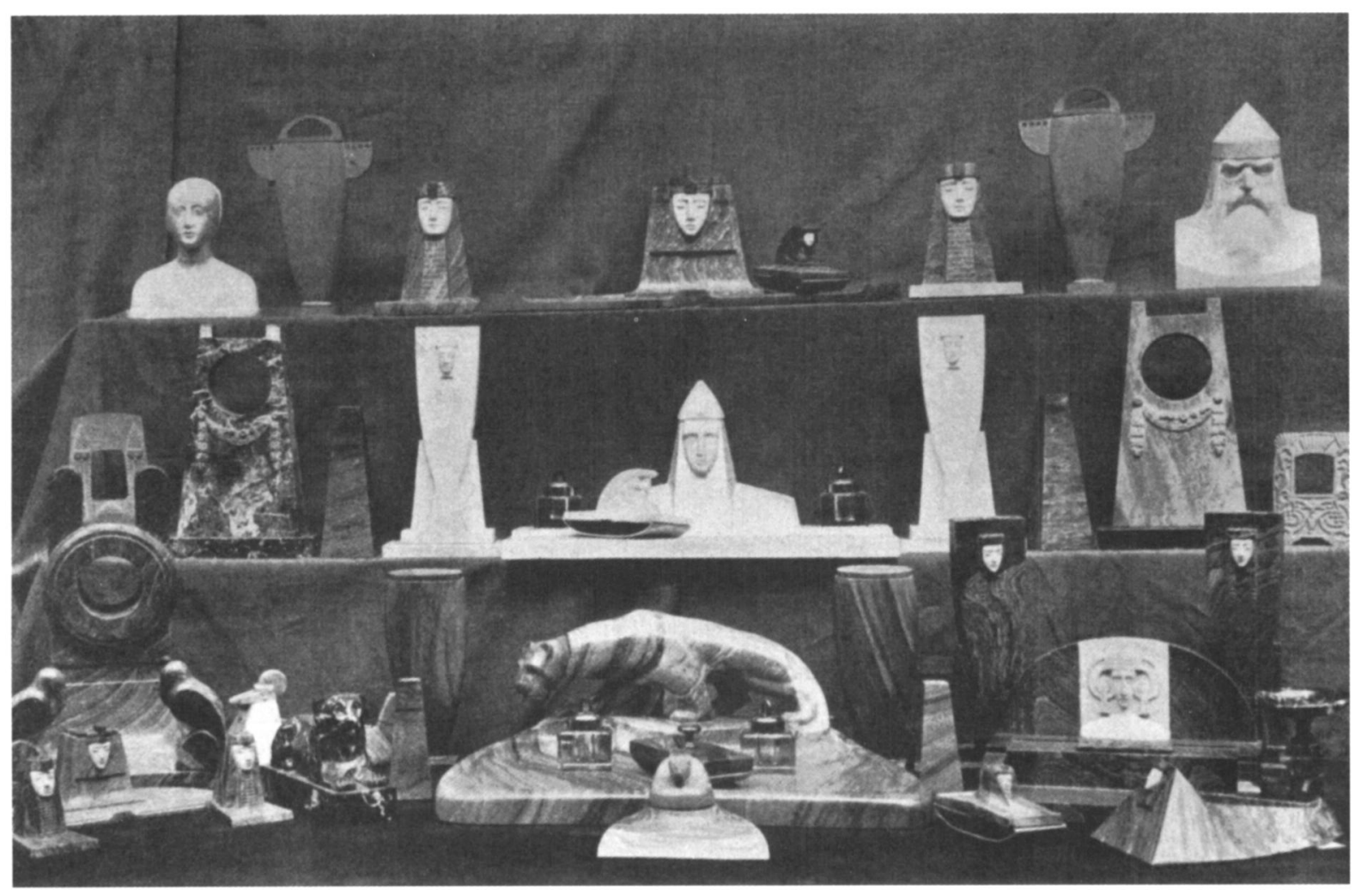


People," and fostering "the enormous role" that industrial art would play in "the international exchange market." 47 Principles that had formed the cornerstone of Globa's reformed Stroganov School in the early 1900spractical training, links with industry through internships, mass art education-were replicated as essential components of the Constructivist ethos. And an unusually high number of avant-garde artists committed to the restructuring of Soviet art and life were themselves former "Stroganovtsy," among them Alexander Rodchenko, Varvara Stepanova, Olga Rozanova, Konstantin Vialov, Aleksei Morgunov, Georgii and Vladimir Stenberg, and Konstantin Medunitsky. ${ }^{48}$

As late as 1922 it was still possible and permissible to acknowledge the obvious continuity between the former Stroganov School and its restructured self, as an encyclopedia entry for that year demonstrates: "Having begun by training craftsmen, the Stroganov School later shifted to educating drawing teachers and factory designers. Around 1900 it began to steer a course toward the training of kustar artists, and finally VKhUTEMAS has made its primary goal the creation of a closer bond between the related branches of our industry." 49 By 1927, however, changes in the political climate had made it extremely difficult to discuss the Stroganov School, or for that matter any prerevolutionary institution, outside the rhetoric of class struggle. The highly critical reminiscences of Ignatii Nivinsky, a former pupil and teacher at the former Stroganov, were symptomatic of this growing intolerance:

I was educated at the Stroganov School during the era of "artistic reaction." The main object and the dominant idea behind our studies was the so-called "applied arts," ornamentation, the accumulation of useless but "chic" details for objects that had no specific purpose. All vital thought was absent from the program, and it was impossible to find the slightest allusion to fundamental problems. Everywhere, in both the classrooms and the workshops, there reigned the desire to satisfy the public taste, a desire that was sustained by the shop that was opened in the school.... In fact, the school produced clever compilers whose ideal was to make objects that "sold well" on the industrial art market. ${ }^{50}$

For the past seventy years, such caricatures of the Stroganov School's complex history have effectively obscured its contribution to design education in Russia. With the passing of Communism and the waning of Modernism, it may now be possible to reintegrate the Stroganov School and all that it stands for-the quest for national identity, the formation of popular culture, the integration of the decorative and functional-into the history of Russian art in its broadest sense. ${ }^{51}$ 


\section{NOTES}

1. The other two schools were both in St. Petersburg. The School of the Society for the Encouragement of the Arts was founded as a drawing school in 1839, and in 1862 expanded to include applied arts. In 1906, when Nikolai Roerich was appointed director, the school was reformed along the lines of the Stroganov School in Moscow. See Nikolai Makarenko, Shkola Imperatorskogo Obshchestva Pooshchreniia Khudozhestv LXXV [The School of the Imperial Society for the Encouragement of the Arts] (Petrograd, 1914). The Shtieglits Central School of Technical Drawing (founded in 1874) was well known for its excellent facilities and technical preparation, and for its fundamentally German faculty and curriculum.

2. The major history of the school before 1860 is $\mathrm{A}$. Gartvig, Shkola risovaniia v otnoshenii $k$ iskusstvam $i$ remeslam, uchrezhdennaia v 1825 Grafom S. G. Stroganovom. Ee vozniknovenie i razvitie do 1860 [The Drawing School Related to the Arts and Crafts, Founded in 1825 by Count S. G. Stroganov. Its Origins and Development to 1860] (Moscow, 1901). See also Moskvich [pseudonym], "Stroganovskoe tsentralnoe uchilishche tekhnicheskogo rizovaniia v Moskve," Iskusstvo $i$ khudozhestvennaia promyshlennost [A Muscovite, "The Stroganov Central School of Technical Drawing in Moscow," Art and Industrial Art] 3 (1898): 286-93; and S. Khan-Magomedov, VKhUTEMAS (Paris, 1990), 145-57.

3. It is worth noting that, whereas by mid-century Russia lagged far behind England in industrial art education, Count Stroganov's school predates by a decade the foundation of the first English school of design, in 1837. The parallels between these first Moscow and London schools are striking. See Quentin Bell, The Schools of Design (London, 1963).

4. Gartvig, Shkola risovaniia, 105.

5. Ibid., 106.

6. Ibid.

7. Ibid., 136.

8. "Only works of painting and some sculptural works actually belong to the free arts. The rest relate more to mechanical works and some, such as carpentry and lathe-turning, are essentially crafts that bear no relation to works of art. ... Their price is usually determined by the number of workers and days required to produce these works, as well as by the value of the materials." Cited in I. A. Pronina, Dekorativnoe iskusstvo v Akademii khudozhestv [Decorative Art in the Academy of Arts] (Moscow, 1983), 140 n. 53.
9. Gartvig, Shkola risovaniia, 282-83.

10. Viktor I. Butovskii, Russkoe iskusstvo i mnenie o nem Viollet-le-Duc i F. I. Buslaeva [Russian Art and the Opinion of Viollet-le-Duc and F. I. Buslaev Regarding It] (Moscow, 1879), 4.

11. Musée d'art et d'industrie de Moscou, Histoire de l'ornement russe du Xe au XVIe siècle d'après les manuscrits, vol. 1 (Paris, 1870), 1.

12. On the Museum of Industrial Art in Moscow, later renamed the Alexander II Museum of Industrial Art, see Natalis Rondot, "Musée d'art et d'industrie de Moscou," Gazette des beaux-arts 25 (July 1868): 82-85.

\section{Butovskii, Russkoe iskusstvo, 172.}

14. Alfred Darcel, "L'art russe," Gazette des beauxarts 17 (March 1878): 285.

15. Vladimir Stasov, "Eshche raz po povodu kritika 'Moskovskikh Vedomostei,"' Sobranie sochinenii ["Once More Regarding the Critic for 'The Moscow Gazette," " Collected Works], vol. 2 (St. Petersburg, 1894), 285.

16. J. Beavington Atkinson, An Art Tour to Russia (London, 1986), 251.

17. A. P-v. [Maxim Gorky], "Khudozhestvennaia promyshlennost," Iskusstvo ["Industrial Art," Art] 5 (1936): 140.

18. Members included N. A. Naidenov (president of the Moscow Stock Exchange Committee), the industrialists M. A. Morozov, V. G. Sapozhnikov, Sergei and Savva Morozov (all heads of major textile concerns), M. S. Kuznetsov (ceramics), M. P. Ovchinnikov (gold and silver), and the railway magnate Savva Mamontov. Novosti dnia [News of the Day] (January 14, 1896): 2.

19. Globa's program is outlined in "S'ezd v Moskve," Novoe vremia ["Congress in Moscow," New Times] 7134 (January 8, 1896): 3.

20. Recueils des compositions des élèves de l'école Stroganoff à Moscou, vol. 1 (Moscow, 1900), 1 .

21. Otchet po imperatorskomu Stroganouskomu Tsentralnomu Khudozhestvenno-Promyshlennomu Uchilishchu za $1909 \mathrm{~g}$ [Report on the Imperial Stroganov Central Industrial Art School for 1909] (Moscow, 1910), 46.

22. "Konkursy," Iskusstvo i khudozhestvennaia promyshlennost ["Competitions," Art and Industrial Art] 9-10 (1899): lxxiv. The jury was made up of both artists and architects on the Stroganov faculty
(Brailovsky, Bykovsky, Zhukovsky, Kekushev, Shekhtel) and those industrialists most closely involved in industrial art education: Savva Mamontov, Serge T. Morozov, M. P. Ovchinnikov, Ivan Tsvetaev, and Petr Shchukhin.

23. Otchet, 20.

24. Ibid., 19.

25. Ibid.

26. Ibid., 21

27. E. Delmar Morgan, "Russian Industrial Art," Journal of the Society of Arts 14 (May 19, 1894): 662.

28. Ibid.

29. A similar point was made by the popular illustrator Ivan Bilibin, who described the ornament on embroidered peasant towels as "so fantastical that if an illustrator used an exact copy in a publication the public would proclaim, "What a decadent.'" Ivan Bilibin, "Ostatki iskusstva v russkoi derevne," Zhumal dlia usekh ["The Remains of Arts in the Russian Countryside," Magazine for Everyone] 10 (1904): 617.

30. "Izvestiia," Khudozhestvennye sokrovishcha Rossii ["News," Art Treasures of Russia] 4 (1901): 63.

31. "Zametka," Iskusstvo $i$ khudozhestvennaia promyshlennost ["A Note," Art and Industrial Art] 12 (1899): 1046.

32. "Vystavka v Stroganovskom uchilishche," Arkhitektumye motivy ["Exhibition at the Stroganov School," Architectural Motifs] 25 (May 1901): 1.

33. B. [article signed with initial only], "Vystavka uchenischeskikh masterskikh Stroganovskogo uchilishcha," Iskusstvo stroitelnoe $i$ dekoratimnoe ["Exhibition of the Student Workshops at the Stroganov School," Building and Decorative Art] 3 (1903): 24.

34. On the ceramic workshop at the Stroganov School, see Klara N. Pruslina, Russkaia keramika [Russian Ceramics] (Moscow, 1974), 91-109.

35. On aspects of the kustar revival movement, see Wendy Salmond, "The Solomenko Embroidery Workshops," Journal of Decorative and Propaganda Arts (Summer 1987): 126-43, and idem, "La riscoperta dell'arte popolare," Ricerche di storia dell'arte 39 (1989): 39-52.

36. On Polenova, see Wendy Ruth Salmond, "The Modernization of Folk Art in Russia: The Revival of the Kustar Art Industries 1885-1917" (Ph.D. diss., University of Texas at Austin, 1989), chaps. 1-2. 


\section{Studies in the Decorative Arts/Spring 1994}

37. See Princess M. K. Tenisheva, Vpechatleniia moei zhizni [Impressions of My Life] (Leningrad, 1991), 208.

38. After the 1917 Revolution, the Stroganov's museum collections and its archive were dispersed and in some cases destroyed in the course of the school's transformation, first into SVOMAS (the Free State Art Studios) and then VKhUTEMAS (the Higher Art and Technical Studios). See Khan-Magomedov, VKhUTEMAS, 151.

39. Zapiski Moskouskogo Arkhitektumogo Obshchestva. Ezhegodnik [Notes of the Moscow Architectural Society. Annual] 1 (1909): xxi.

40. The statute instituted a four-tier system of education institutions: drawing schools, arts and crafts workshops, industrial art schools (shkoly), and industrial art institutes (uchilishcha). See E. Baumgarten, "Khudozhestvenno-promyshlennoe obrazovanie," Zodchii ["Industrial Art Education," The Architect] 28 (1902): 322.

41. Nikolai Root, "Khudozhestvenno-promyshlen- noe obrazovanie v Rossii i za granitsei," Zodchii ["Industrial Art Education in Russia and Abroad," The Architect] 1 (January 3, 1910): 1.

42. Nikolai Root, "Khudozhestvenno-promyshlennoe obrazovanie i Kamenets-Podolskaia khudozhestvenno-remeslennaia uchebnaia masterskaia," Iskusstvo v Iuzhnoi Rossii ["Industrial Art Education and the Kamenets-Podolsk Arts and Crafts Training Workshops," Art in Southern Russia] (Kiev) 9-10 (1913): 405.

43. Georgii Lukomskii, "Vserossiisskaia vystavka v Kieve," Apolon ["The All-Russian Exhibition in Kiev," Apollo] 7 (September 1913): 72.

44. Among them were E. G. Teliakovskii, B. N. Lange, and Z. D. Kashkarova.

\section{Otchet, 49}

46. On this, see Christina Lodder, Russian Constructivism (New Haven, 1983), 109-44.

47. Ibid., 112-13.
48. For biographical data on these and other artists of the Russian avant-garde, see The Avant-Garde in Russia 1910-1930. New Perspectives, ed. Stephanie Barron and Maurice Tuchman, exh. cat. (Los Angeles: Los Angeles County Museum of Art, 1980).

49. N. Tarasov, "Stroganovskoe uchilishche tekhnicheskogo risovaniia v Moskev," Entsiklopedicheskii slovar russkogo bibliograficheskogo instituta Granat ["The Stroganov School of Technical Drawing in Moscow," Encyclopedia of the Granat Russian Bibliographical Institute], vol. 41, pt. 5 (Moscow, 1922), col. 33.

50. Quoted in Khan-Magomedov, VKhUTEMAS, 152.

51. The fact that the school survives to this day, as the Moscow Higher Industrial Art School (formerly the Stroganov), is a tribute to its exceptional ability to survive political and social upheavals intact. The school and its museum (now considerably depleted) are located at 9 Volokolamskoe Shosse in Moscow. 